This PDF is a selection from a published volume from the National Bureau of Economic Research

Volume Title: How the Financial Crisis and Great Recession Affected Higher Education

Volume Author/Editor: Jeffrey R. Brown and Caroline M. Hoxby, editors Volume Publisher: University of Chicago Press

Volume ISBN: 978-0-226-20183-2 (cloth); 978-0-226-20197-9 (eISBN)

Volume URL: http://www.nber.org/books/brow12-2

Conference Date: September 27-28, 2012

Publication Date: December 2014

Chapter Title: Competition among University Endowments

Chapter Author(s): William N. Goetzmann, Sharon Oster

Chapter URL: http://www.nber.org/chapters/c12858

Chapter pages in book: (p. $99-126)$ 


\title{
Competition among University Endowments
}

\author{
William N. Goetzmann and Sharon Oster
}

\subsection{Introduction}

Why did so many American universities find themselves with such troubling liquidity issues during the Great Recession of 2008 and 2009 when their endowments suffered large declines? With endowments in the billions of dollars, and what had long been touted as conservative spending policies, many observers outside the academy were surprised by how difficult the financial crisis was for universities like Harvard, Yale, and Stanford. Within the academy, many have talked about the role played by the change in asset allocation policies that occurred in the last several decades, particularly in the increased use of alternative investments. For example, Lerner, Schoar, and Wang (2007) show that this change in asset allocation increased the skewness in endowment size, paradoxically leading the now-much-richer universities to rely more heavily on endowment returns to fund operations. At the same time, the increased reliance on relatively illiquid, alternative investments by many universities exacerbated difficulties in adjusting to the market downturn, at least in the short run.

Our chapter focuses on the process by which universities decide to change their asset allocation policies. We are particularly interested in the deci-

William N. Goetzmann is the Edwin J. Beinecke Professor of Finance and Management Studies and the director of the International Center for Finance at the Yale School of Management and a research associate of the National Bureau of Economic Research. Sharon Oster is the Frederic D. Wolfe Professor of Management and Entrepreneurship at the Yale School of Management.

We thank John Griswold, Minhua Wan, and Larry Itavares for their help and advice. We thank Commonfund and NACUBO for providing data for research. We thank the Yale, Harvard, and Princeton endowment offices for providing data. All errors are the responsibility of the authors. For acknowledgments, sources of research support, and disclosure of the authors' material financial relationships, if any, please see http://www.nber.org/chapters/c12858.ack. 
sions leading to the adoption of alternative investments. We will argue and provide some evidence in favor of the proposition that competition in the product market of universities, particularly in the competition for quality students, influenced patterns of diffusion of innovation in asset allocation. We argue that the dynamic patterns that we see in asset allocations in university endowments are consistent with an arms race model of universities, in which the competitive pressures in the "real" part of the university business (research and teaching) drive an imitative diffusion of endowment policies across schools in similar submarkets.

Using data on prospective applicant comparison behavior to identify clusters of competitive universities, we find evidence that schools competing in the same markets for students follow similar asset allocation policies over time, even when we hold endowment size and other school characteristics constant. We further find that when a school's endowment return lags relative to its immediate rival, it systematically changes its asset allocation. Thus, in a very real sense, the competitive environment of US education may have contributed to their exposure to illiquid asset classes such as private equity during the period leading up to the Great Recession and left them with a sudden shortage of cash when the recession hit.

Section 3.2 of this chapter provides some historical background on asset allocation by universities in the United States, and sketches our theory of the link between product market competition and asset allocation choices. Section 3.3 describes the data we use to provide evidence for our theory, section 3.4 describes our results, and section 3.5 discusses the implications.

\subsection{Some History and a Theory}

University endowments have long been at the forefront of innovative investment. For example, Goetzmann, Griswold, and Tseng (2010) document a strategic shift in university endowments toward equities in the 1920s and 1930s, despite the financial crisis at the time. This shift proved beneficial in the long run, but caused observers to question its wisdom in the short run.

Prior to the 1980s virtually all universities and colleges restricted themselves to domestic equities, bonds, and cash. Even at Harvard and Yale, the two innovators in asset allocation policy, the share of endowment devoted to these traditional classes was dominant in 1985. Our first three figures capture the central and dramatic changes in the portfolios of the Harvard, Yale, and Princeton endowments over the last twenty-five years. ${ }^{1}$ Figure 3.1 shows the decrease in allocation to US publicly traded equities by the three endowments over the period from 1985 to 2011. The Yale and Princeton stock holdings decreased from over 60 percent to less than 10 percent in the

1. We thank the endowment offices of Harvard, Yale, and Princeton for the data for these figures. 
time period. Harvard's stock holdings dropped from 40 percent to about 10 percent at the end of the period. Yale and Princeton's shift from public equities appears to be partially explained by substitution into private equity. Figure 3.2 shows a dramatic rise in Yale and Princeton's private equity allocation from below 5 percent to over 30 percent. The speed with which interest in the new asset classes grew and the movement away from both domestic equities, and more dramatically bonds, is striking. We note in particular that at the time of earlier substantial recessions in 1980-1981 and then later in the early 1990s, the asset allocations of the major research universities were much less vulnerable, with much more reliance on fixed income and much less private equity. Figure 3.3 shows a sequential adoption of new investment "technology" over the 1990s. From 1990 to 1998, first Yale then Princeton then Harvard began to invest in hedge funds - that is, marketable alternatives. These investments reached a peak in the early twenty-first century and have since tapered to about a 20 percent allocation. While some of the recent shifts from marketable alternatives and publicly traded equities may have been driven by liquidity needs around the financial crisis (and conversely the difficulty in liquidating private equity positions at that time), the broad trends are clear. In 1985, all three institutions were heavily invested in domestic equity and fixed income. Harvard had 69 percent of its endowment invested in domestic equities and bonds, while Princeton had 85 percent and Yale 78 percent. None of the three institutions had any investment in absolute returns and all were relatively light on private equity, with Harvard leading at 7 percent, Yale at 3 percent, and Princeton at 2 percent. These strategies virtually reversed themselves over the twenty-five-year period.

The similarities in the diffusion of the new asset allocation strategies of Harvard, Yale, and Princeton are even more striking when mapped against the strategies of the rest of the universe of colleges. In the $\mathrm{NACUBO}^{2}$ database, as late as 2000 the average university endowment was still invested more than 50 percent in domestic equities, with under 2 percent in private equity and hedge funds (Brown, Garlappi, and Tiu 2010). Figure 3.4 compares the time trend of domestic equity investments for Harvard, Yale, and Princeton with the general NACUBO population of schools from 1989 to 2005.

The similarities in the rate of adoption of the new financial models by Harvard, Yale, and Princeton could, of course, be attributed to a number of factors. In all industries, there are early and late adopters of innovations, and we know that early adopters differ systematically from later adopters. On the firm level, early adopters tend to be those firms with the most to gain from an innovation and firms with the requisite complementary assets.

2. NACUBO, the National Association of College and University Business Officers, has maintained an annual survey of its members for a number of years; this has been managed by the Commonfund since 2009 and combined with the Commonfund's own survey of college and university endowment offices. The Commonfund is a nonprofit investment management firm serving primarily endowments and foundations. 


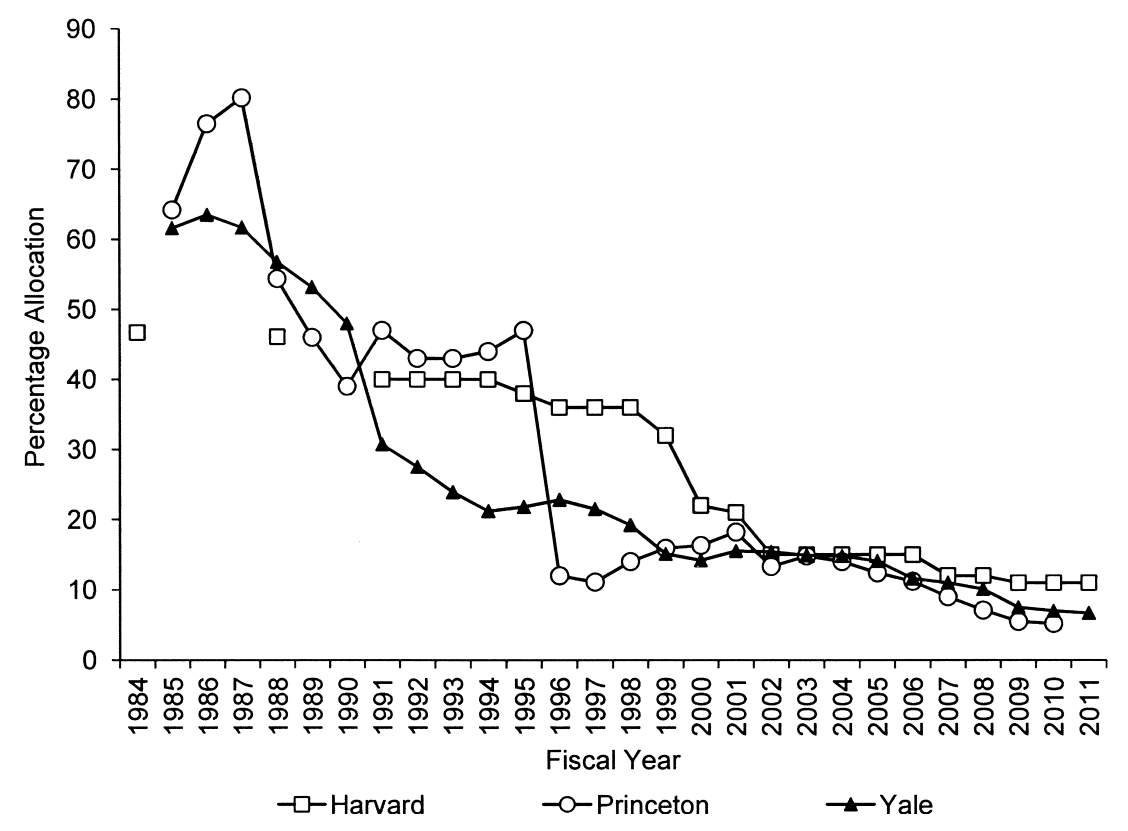

Fig. 3.1 Allocation to US publicly listed equities by Yale, Harvard, and Princeton endowments, 1990-2011

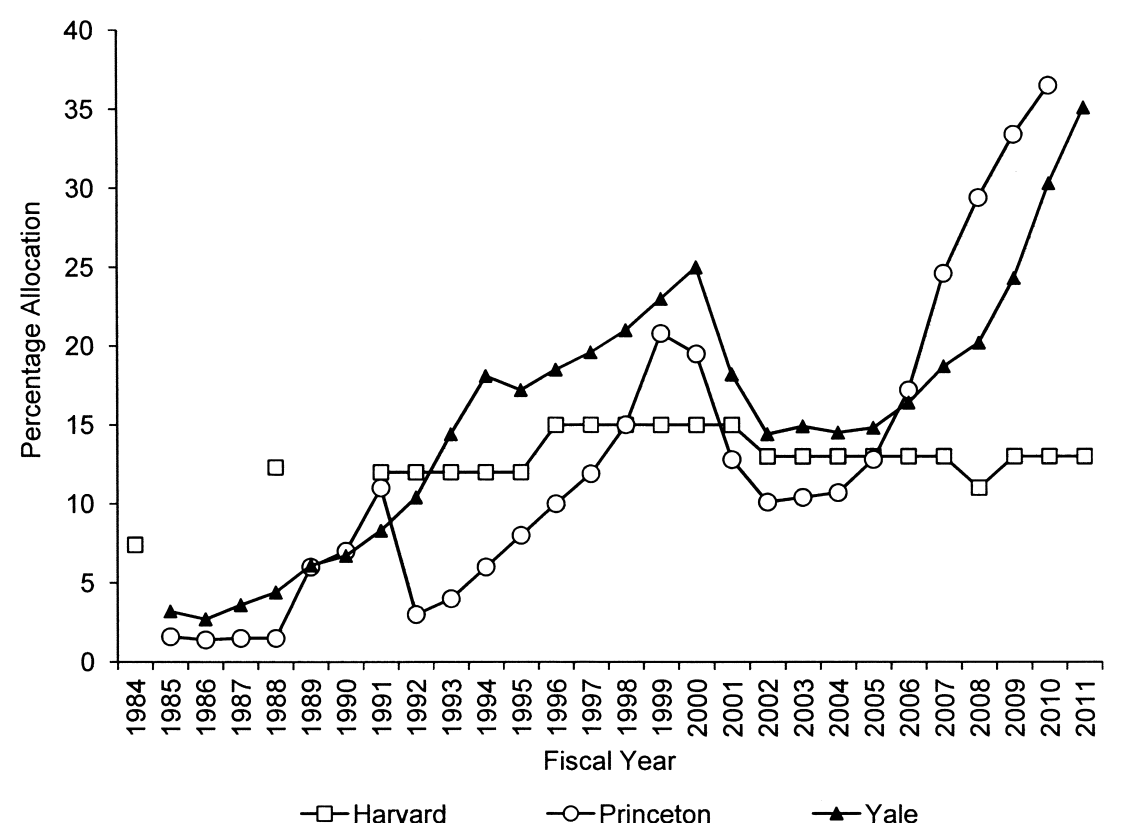

Fig. 3.2 Allocation to private equity by Yale, Harvard, and Princeton endowments, 1990-2011 


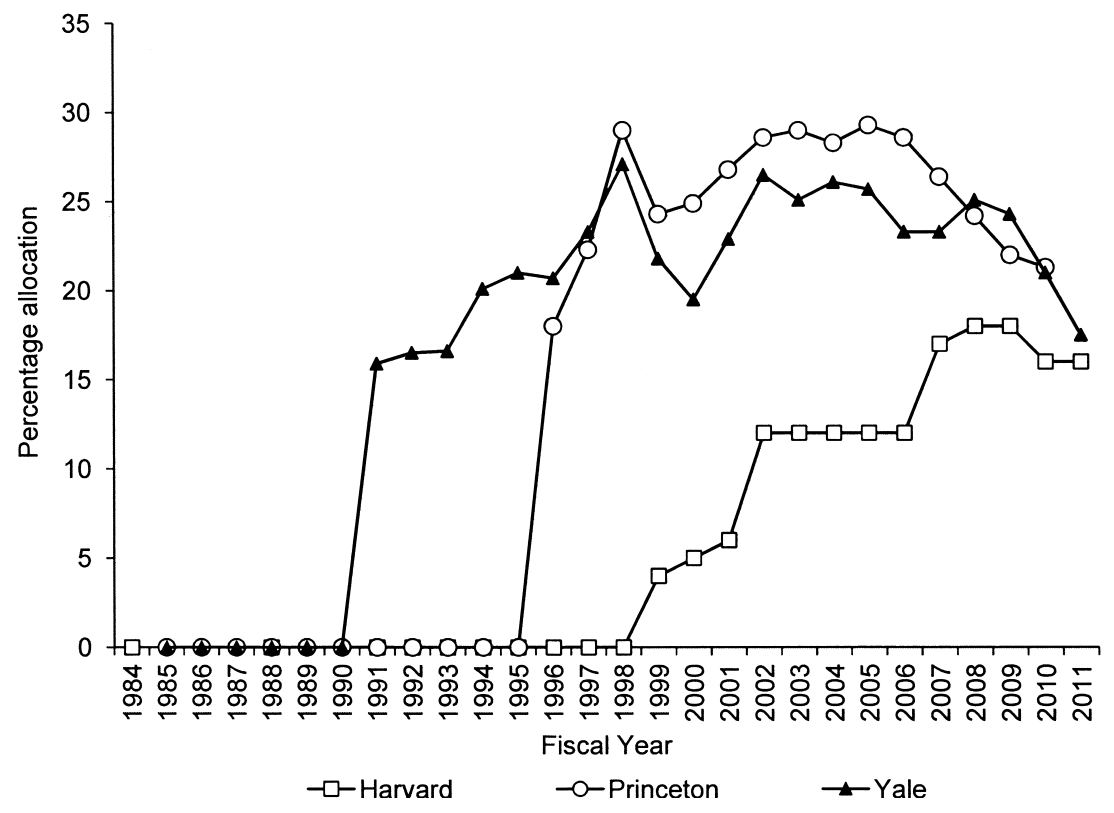

Fig. 3.3 Allocation to marketable alternatives by Yale, Harvard, and Princeton endowments, 1990-2011

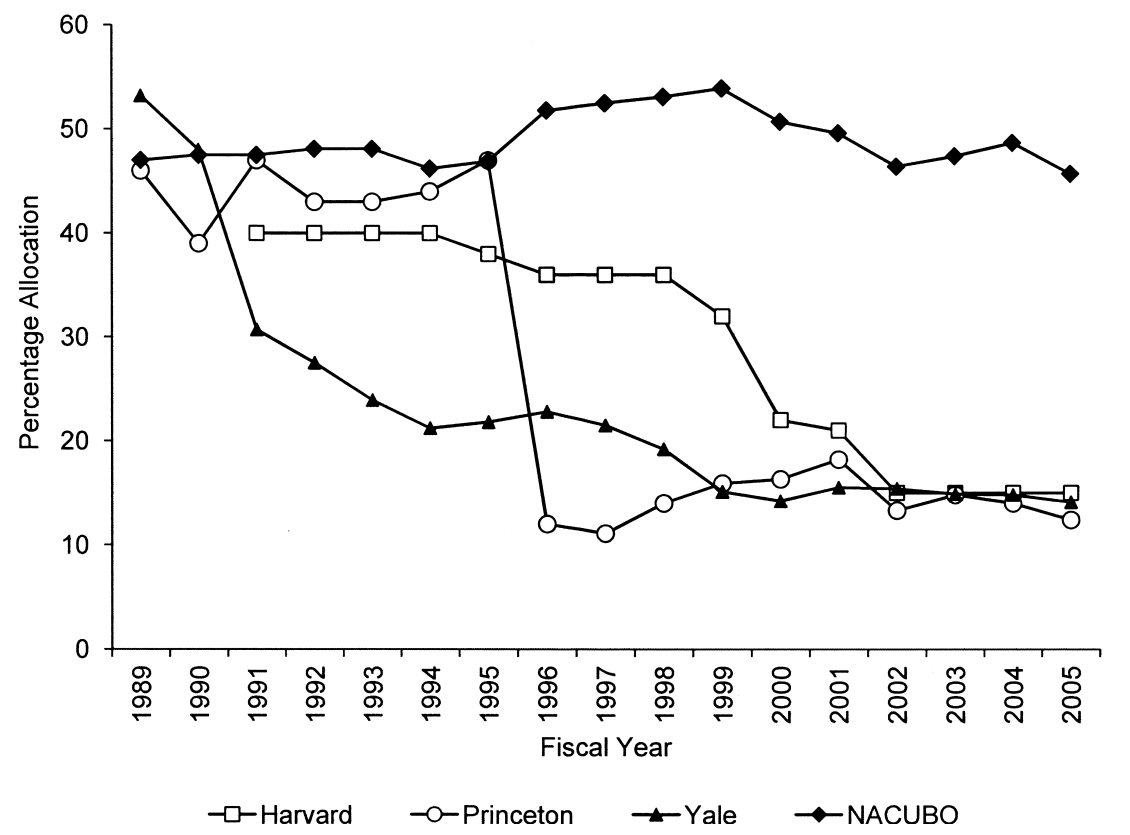

Fig. 3.4 Allocation to US publicly listed equities by Yale, Harvard, Princeton, and NACUBO, 1989-2005 
Early adopters also tend to cluster geographically or belong to the same trade organizations, which facilitates transmission of new ideas (Griliches 1957; Oster 1982). For example, Harvard, Yale, and Princeton were all large endowments, all located in the East, and all part of the Ivy League. Surely, these commonalities facilitated the diffusion of innovation across the three.

But there is another feature of Harvard, Yale, and Princeton that we believe plays a fundamental role in their common adoption of endowment strategies: the strong competition among the three in their product market. References to H-Y-P as the goal of many elite high school scholars are common; close rankings of the three are also evidenced in more sophisticated revealed-preference rankings (Avery et al. 2004). We argue that this product line competition also affects investment decisions.

To understand why product market competition might influence the diffusion of investment strategies, we need to think about the role of endowments for universities more broadly. The classic argument in favor of an endowment beyond that required to accommodate cash flow swings is to create intergenerational equity across students, by creating a perpetual flow of real income to support university activities (e.g., Litvak, Malkiel, and Quant 1974; Tobin 1974). Sometimes this goal is referred to as "preserving purchasing power" from a gift (Swensen 2000, 35).

Some have interpreted this mandate as requiring that spending rules and investment returns be managed to maintain the real value of the endowment spending using, for example, the Higher Education Price Index (HEPI) to measure changes in the costs of inputs used by universities.

We would argue that the objective of intergenerational equity is more complicated than simply maintaining a level real value of resources. In producing a superb education, two key ingredients are faculty and students. Student quality is especially important: better students attract better faculty, peer effects are important in improving educational outcomes, and quality of student on the incoming side is clearly highly correlated with student outcomes. (For evidence on the importance of peer effects see Epple, Newlon, and Romano [2002] and Burke and Sass [2008]). It is for this reason that various measures of student quality and student admissions choices play such a large role in the many college rating systems. U.S. News \& World Report, for example, weights SAT scores 15 percent in devising their college ranking and adds another 25 percent weight for another, more subjective measure of student quality. Notice, however, that while changes in competition for faculty will arguably show up (at least on average) in the Higher Education Price Index, competition for students will typically not be reflected in the price index. Schools compete for students via increasing resources available to them such as scholarships, housing, and athletic facilities (Hoxby [2009] describes this process). They thus bid up the number of inputs needed to produce good students rather than the price of those inputs. Perhaps more importantly, the competition for students occurs in very narrow markets. 
Colleges ranked among the top ten schools rarely compete for students with schools ranked 100 rungs below them. As we describe later in this chapter, there is reason to think that the narrow competition for students within quality bands of schools may have increased over time. With local competition for a key input like students, preserving intergenerational equity requires that universities keep up with their proximate rivals and not just maintain the real value of their assets, as they might do in a case in which their inputs were widely traded. If Yale wants to produce as good an education in 2020 as it did in 2010 it needs to preserve its competitive position vis-à-vis the other narrow set of colleges with which it competes for students. If the real value of Harvard's endowment doubles in the next ten years, and Yale's remains flat, Yale will no longer be able to compete for the same quality of students that it attracted earlier.

A goal of producing the same level of service over time, in a market in which groups of universities compete for scarce resources, creates a linkage across those universities in both asset allocation decisions and spending rules. We will observe a form of arms race in which universities focus on ensuring adequate resources for tomorrow's battlefield. There are, as a result, strong competitive pressures that may encourage adoption of similar policies within competitive submarkets. This is the hypothesis we will explore in this chapter.

\subsubsection{Related Research: Keeping Up with the Joneses}

Economic research has not addressed competitive endowment behavior to any large extent, but it has intensely examined competitive household investment behavior. Much of this work has focused on the effects of the utility for relative wealth on asset price dynamics in an equilibrium setting (e.g., Abel 1990; Gali 1994; Chan and Kogan 2002). Generally called "keeping up with the Joneses" (KUJ) or "catching up with the Joneses," this research has been used to explain the equity risk premium, as well as labor and consumption dynamics. Gali (1994), for example, shows that when consumption demand is positively related to average consumption, the equity premium falls. Bakshi and Chen (1996) examine a model in which relative wealth determines status and show it leads to excess market volatility. Ravina (2005) empirically identifies KUJ behavior in consumption through credit cards. These asset-pricing results may be tangentially relevant to the endowment universe in asset markets with limited capacity, but this question is not the focus of the current chapter.

Most relevant for our study, however, are papers by DeMarzo, Kaniel, and $\operatorname{Kremer}(2005,2008)$. They analyze how investors respond to local economic factors. In a KUJ setting, when a subset of investors (the Joneses) within a community takes a large position in a particular security for hedging reasons - or even irrational reasons - this can induce herding by others concerned with keeping up with them. This setting leads to underdiversification, 
increased investment in risky assets, and may lead to asset market bubbles. They argue that a diversified portfolio becomes a community asset - inducing positive externalities for competitors. In this case, the innovators in the endowment universe characterized by KUJ preferences can have positive or negative externalities. If they become more diversified - or choose a strategy that is superior in meeting the long-term goals of a university, then this has a positive spillover to their competitors. On the other hand, if the innovator picks a strategy that is optimal for himself, but is not replicable or not optimal for imitators, this can have negative external consequences. For example, if the leader invests in an asset class - such as venture capital - with limited capacity, this may generate increased demand for this specific asset and drive up the price, or lead imitators to invest in lesser-quality venture funds.

Also related to our work is the investment funds tournament literature (e.g., Chevalier and Ellison 1997; Sirri and Tufano 1998; Brown, Goetzmann, and Park 2001; Brown, Harlow, and Starks 1996). These papers study the behavior of investment managers in a competitive setting in which capital flows reward positive performance. Chevalier and Ellison (1997) and Sirri and Tufano (1998) document asymmetric rewards to performance, which implies option-like compensation that can induce risk taking to stretch for high returns. Brown, Harlow, and Starks (1996) and Brown, Goetzmann, and Park (2001) focus on risk taking by mutual fund managers and hedge fund managers. The former shows increased risk taking by funds that lag their peers after the first half of the year. The latter shows that positive performance relative to peers in the hedge fund industry is associated with reduced risk taking in subsequent periods, consistent with preserving relative performance.

University endowments differ considerably from households and managed funds, but the studies cited above offer useful frames for understanding the effects of competition in the endowment market. Endowments are a bit like mutual funds and hedge funds because their managers operate within a labor market in which track record (and survival) are important determinants of employment and compensation. Endowments are also a bit like households in that they are confronted with a savings and investment problem conditional on a set of mission objectives. These mission objectives may include a dimension of relative consumption — or even relative wealth.

\subsubsection{Strategic Competition among Universities}

There is considerable research on the competition among universities. Epple, Romano, and Sieg (2003, 2006), for example, find that competition among universities generates a rigorous quality hierarchy in which a few select schools have market power. These researchers abstract away from the role of the university endowment as either a metric for market power or a determinant of it. Other research examines trends in student preferences for universities consistent with increasing mobility. Hoxby (2009) finds "the elasticity of a student's preference for a college with respect to its proximity 
to that student's home has fallen substantially over time and there has been a corresponding increase in the elasticity of each student's preference for a college with respect to its resources and peers" (96). This, in turn, may have intensified the competition among "national" universities. In the mid-1950s, 20 percent of the Yale undergraduate population came from Connecticut. ${ }^{3}$ By 2011, much of that specialization had gone by the wayside: in 2011, only 6 percent of the Yale student body was from Connecticut, fewer than those who came from outside US borders. At the elite colleges, the diminishing role of family connections also serves to increase competition across schools. In the mid-1950s, 25 percent of the enrollees at Yale were the sons of Yale fathers. ${ }^{4}$ By 2011, this number had fallen to 10 percent (and, of course, included daughters of Yale mothers and fathers). This increased competition naturally increased the importance of maintaining financial parity to enable selective colleges to maintain their ability to attract high-quality students in what has become an international marketplace.

Scholars have also recognized the effects of competition in the market for professors. In the humanities, Shumway (1997) has derided the "star" system as a threat to merit-based evaluation of research in literary studies. Volkwein and Sweitzer (2006) report that full-time professor salaries are positively correlated to prestige rankings of universities and colleges. Bastedo and Bowman (2011) find that published rankings of colleges influence future revenues. The clear implication is that a larger endowment makes possible higher faculty salaries, enhanced prestige, and in turn this may generate future economic benefits as well.

If there is an arms race in university endowment management, born of increased competition for key inputs, we should expect to see a higher degree of similarity of investment strategies for schools that most directly compete. The data we looked at for Harvard, Yale, and Princeton is suggestive, but we turn now to describe the broader data we will use to explore this hypothesis.

\subsection{The Data}

We are interested in exploring the similarities in asset allocation patterns among colleges that compete most directly with one another in the product market, here defined as the market for students. We thus need data on asset allocations by schools and by narrow categories as well as data on the levels of competition among schools.

\subsubsection{Asset Allocation}

In describing the endowment assets and investment policies of universities and colleges we relied on the annual NACUBO-Commonfund Study

3. See the Yale Office of Institutional Research (OIR) website at http://oir.yale.edu/.

4. Ibid. 
of Endowments. The survey covers 1,033 funds associated with 1,261 universities or colleges for the July to June fiscal years 2006-2011. It collects comparative data on endowment investment policies and practices across the participating universe of US colleges and university endowments. The data are self-reported by university endowment offices and not always complete for each year, although the annual rate of compliance is very high. As necessary, we adjust our empirical analysis for competing universities (for example, some state institutions) that have a common endowment. With these and other data-driven exclusions, 947 universities remain in our sample.

Much of our analysis focuses on the types of assets held by university funds. The NACUBO-Commonfund sample classifies assets into domestic equities, fixed income, international equities, alternative strategies, and cash/other. Each category is broken down further. For our analysis, we are especially interested in the subgroups within the alternative asset category: private equity, real estate, venture capital, energy and natural resources, marketable alternatives (i.e., hedge funds), and distressed debt. As we have already seen in the data on Harvard, Yale, and Princeton, the major change in endowments since 1985 was the movement into alternatives. These alternative assets have three features of interest. First, most of these alternative asset categories are actively managed so that a necessary component of the value proposition of the investment involves access to skillful managers. When top managers have limited capacity, they may not be able to accommodate both innovators and followers. Second, alternative assets are generally less liquid than other asset categories. Indeed, one of David Swensen's key insights is that part of the returns to alternative assets comes from the "liquidity premium," that is, compensation for holding illiquid, nonmarketable assets. The common notion, at least until 2008, was that endowments were patient investors who could "harvest" the liquidity premium that shorter-term investors must avoid. Finally, alternative assets were thought to be attractive because they were uncorrelated with the stock and bond markets, and thus played a role in reducing portfolio volatility.

The NACUBO data provides, for each responding college, both the percent investments in each asset class and the return achieved for that class, if available. These data allow us to benchmark the endowments' self-reported performance by asset class. In addition, for some years, funds are asked whether their marketable alternative investments underperformed, met expectations, or exceeded expectations.

We are particularly interested in tracing the diffusion of allocation strategies across schools that compete. Part of this analysis will involve looking at how closely allocations match at various points in time. But we also have more direct data on planned changes by endowment managers that we will exploit in our empirical work. A key survey question we rely on for our analysis is whether the fund is considering changing "its approach to con- 


\begin{tabular}{l|c|c|c|c}
\hline & Domestic Equities & Fixed Income & International Equities & Alternatives \\
\hline 2006 & 45.534 & 19.9669 & 13.5706 & 17.703 \\
2007 & 42.3251 & 17.7306 & 15.8226 & 18.941 \\
2008 & 37.9991 & 18.8349 & 15.1108 & 23.848 \\
2009 & 33.5849 & 21.6286 & 14.269 & 23.024 \\
2010 & 32.3573 & 21.7605 & 14.7836 & 24.976 \\
2011 & 32.4115 & 18.975 & 16.463 & 26.368 \\
\hline
\end{tabular}

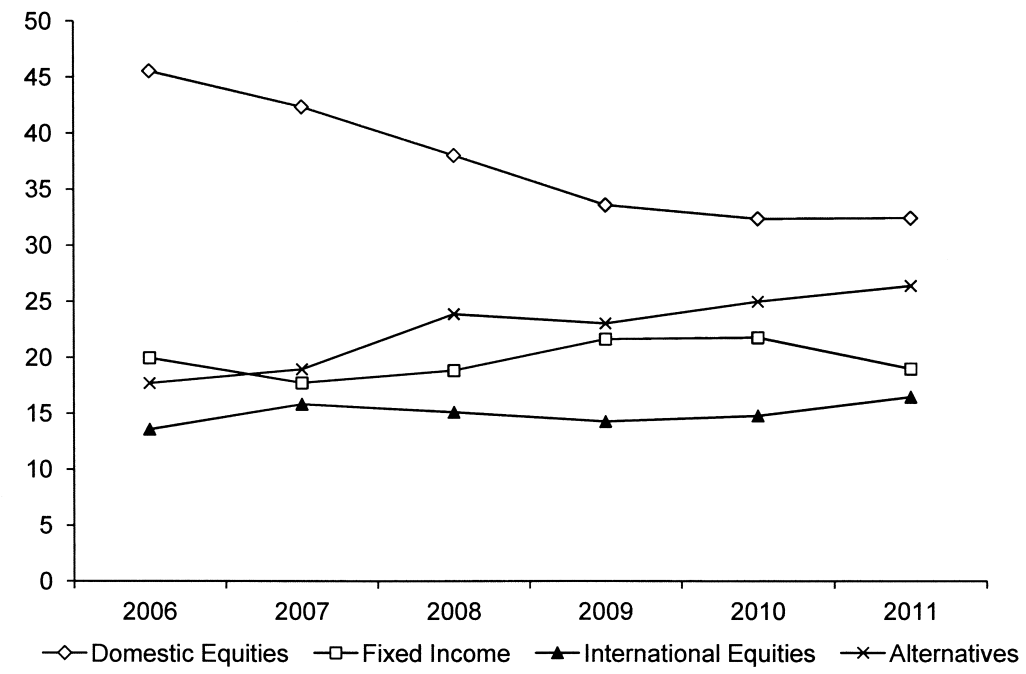

Fig. 3.5 Change in asset allocation over time

structing the asset allocation" of the portfolio and, if so, the nature of the contemplated change. Thus we are potentially able to connect the decisions to change investment strategy to the behavior of competitive rivals.

The key data set we use from the survey is a time-series, cross-section panel of individual endowment asset allocations. Figure 3.5 shows the aggregate allocation of university assets in the sample to major asset classes: domestic equities, fixed income, international equities, and alternatives. The shift from domestic equities to alternative assets is clearly evident, though as we see, it happened later in the general population than it did in the HYP sample. This shift away from domestic equities by colleges is well documented. Lerner, Schoar, and Wang (2007), using data beginning in 1992, find a dramatic doubling of the share of the average endowment invested in alternatives from 9 percent in 1993 to 18 percent in 2005. 


\begin{tabular}{l|c|c|c}
\hline & large funds & medium funds & small funds \\
\hline 2006 & 30.347 & 16.532 & 6.361 \\
2007 & 31.296 & 17.206 & 5.644 \\
2008 & 37.877 & 21.024 & 7.094 \\
2009 & 40.98 & 22.406 & 10.35 \\
2010 & 43.235 & 23.587 & 10.559 \\
2011 & 43.186 & 23.655 & 10.328 \\
\hline
\end{tabular}

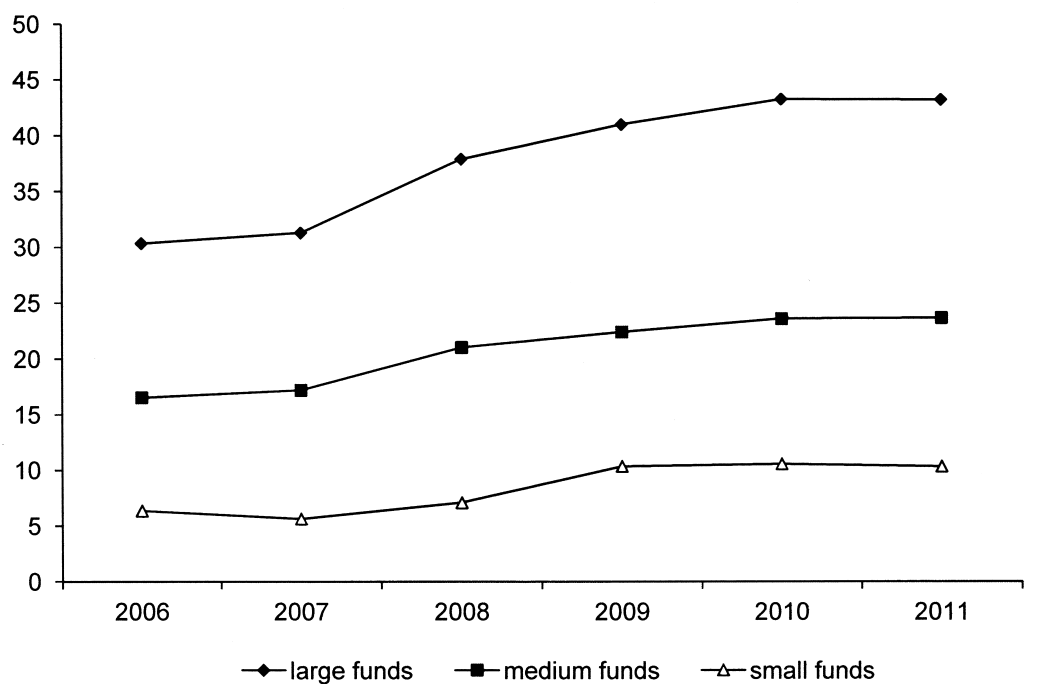

Fig. 3.6 Change in alternatives over time

As we suggested earlier, there are a number of features of colleges that are correlated with asset allocations. Size of endowment clearly affects asset allocations; the substitution toward alternative investments is even more dramatic for larger endowments, which moves from 30 percent allocation in 2006 to 43 percent in 2011. Clearly, larger funds have capabilities different from smaller ones. Differences in the investment strategies of the small and large funds are evident in figure 3.6. There is also some regional variation in portfolios. Figure 3.7 separates endowments by the first-digit zip code regions and shows the greater exposure of the New England and Mid-Atlantic areas to alternative assets. The regional pattern we see is consistent with other regional diffusion models, given the fact that the move to alternatives began, as we saw earlier, at Harvard, Yale, and Princeton, all located in the mid-Atlantic and New England areas. 


\begin{tabular}{l|c|c|c|c}
\hline \multicolumn{1}{c|}{ First Zip } & avg_MktAlt (\%) & avg_VC (\%) & avg_PE (\%) & avg_TotalAlt (\%) \\
\hline O New England & 14.437 & 1.335 & 6.872 & 27.747 \\
1 NY-PA & 12.631 & 1.176 & 5.333 & 23.610 \\
2 Mid-Atlantic & 15.365 & 1.680 & 5.561 & 30.267 \\
3 South East & 9.808 & 0.694 & 4.451 & 19.706 \\
4 Michigan - KY & 10.380 & 1.301 & 5.504 & 21.143 \\
5 MT to WI & 8.396 & 0.813 & 4.961 & 17.853 \\
6 Mid West & 7.667 & 1.008 & 5.431 & 18.084 \\
7 TX \& Oil & 10.537 & 0.781 & 5.797 & 22.754 \\
8 Rockies & 10.501 & 0.440 & 4.948 & 20.276 \\
9 West Coast & 9.657 & 1.404 & 5.571 & 22.196 \\
\hline
\end{tabular}

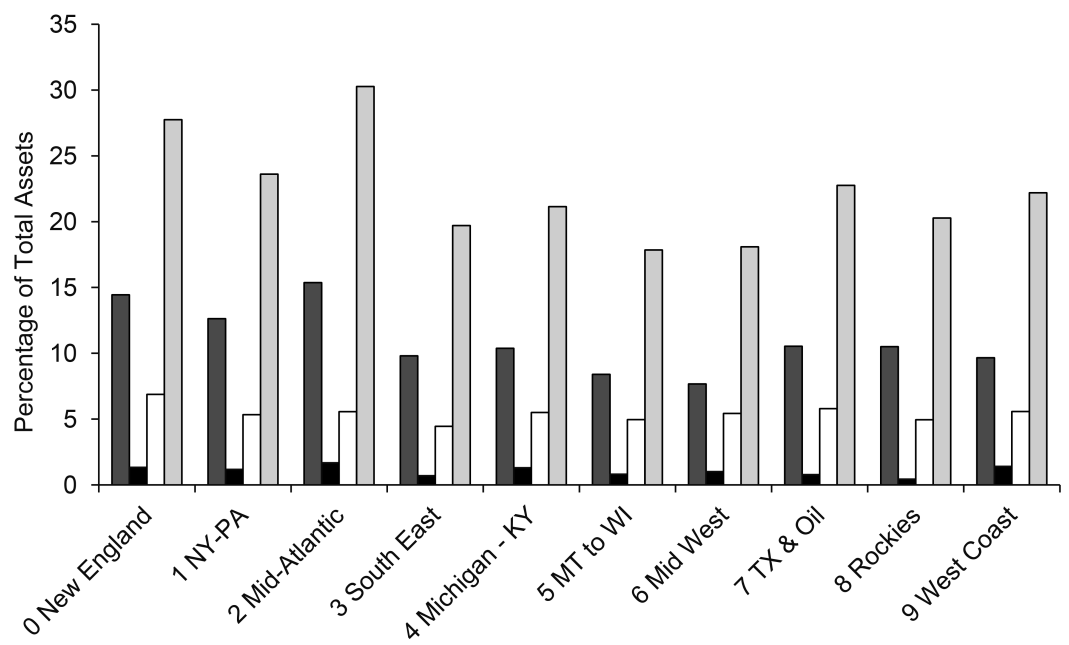

$\square$ Mkt Alternatives $\square$ Venture Capital $\square$ Private Equity $\square$ Total Alternatives

Fig. 3.7 Regional distribution of the use of alternative assets (percentage of total assets)

\subsubsection{Data on School Competition}

Universities compete in many markets from the labor market to the market for government grants. For our work, a key market is the market for students. We are interested in finding a measure of the degree of head-tohead competition among colleges for students.

The search process for information about colleges for students and their families has, like much else, transitioned to the web. There are a few major websites that aggregate useful information about universities and also pro- 
vide software tools for building portfolios of schools for potential consideration. For our measure of competition, we rely on one of these sites: Cappex.com.

Cappex claims to have nearly three million student users and it covers roughly 3,000 colleges and aggregates basic information about the school and the application process. On the Cappex web page for each college, there is a section entitled "students also considered," which includes the names of ten other schools visited by other users who visited that particular college page. These other schools appear to be ranked in order of frequency of visit from one school to the next. In other words, students who considered school $\mathrm{X}$ also considered these ten other schools. In effect, we are able to observe comparison shopping by college students browsing schools. ${ }^{5}$

Table 3.1 provides a sampling of the pairings we found in this exercise along with data on the relative ranking of the colleges using the revealed preference rankings found by Avery et al. (2004). In the table we have provided information on the top ten browsing pairs for five schools in the sample; in the empirical work we aggregate these ten competitors as our measure of school competition. The pairings seem broadly sensible. Thus for Yale, we see Harvard and Princeton appear, while for the San Francisco Conservatory of Music we find the Manhattan School of Music and the New England Conservatory of Music.

\subsection{Results}

Table 3.2 provides some descriptive data on the sample of college funds we used in our analysis. Two-thirds of the institutions in the sample are private schools and the mean endowment size is almost $\$ 500$ million with a substantial range.

Table 3.3 reports the results of regressions explaining allocation to alternative assets. In panel A, the dependent variable is the percent of a university's endowment invested in alternatives at the end of the fiscal year. In column (1) we report results from a pooled sample, using year dummies. In the remaining columns, we break the data out year by year, allowing coefficients to vary over the years. The results are qualitatively similar, so we will focus on the pooled regression. Panel B presents the same analysis for the percent of endowment invested in marketable alternatives (i.e., hedge funds). ${ }^{6}$

Not surprisingly, the results indicate that larger schools, both in terms of number of students and size of the endowment, have, on average, higher shares of their endowments in alternatives. For marketable alternatives,

5. Our data was downloaded in mid-December 2011.

6. For comparison, we also use the single-closest school on the list as the nearest competitor. The results are slightly stronger in that specification. 


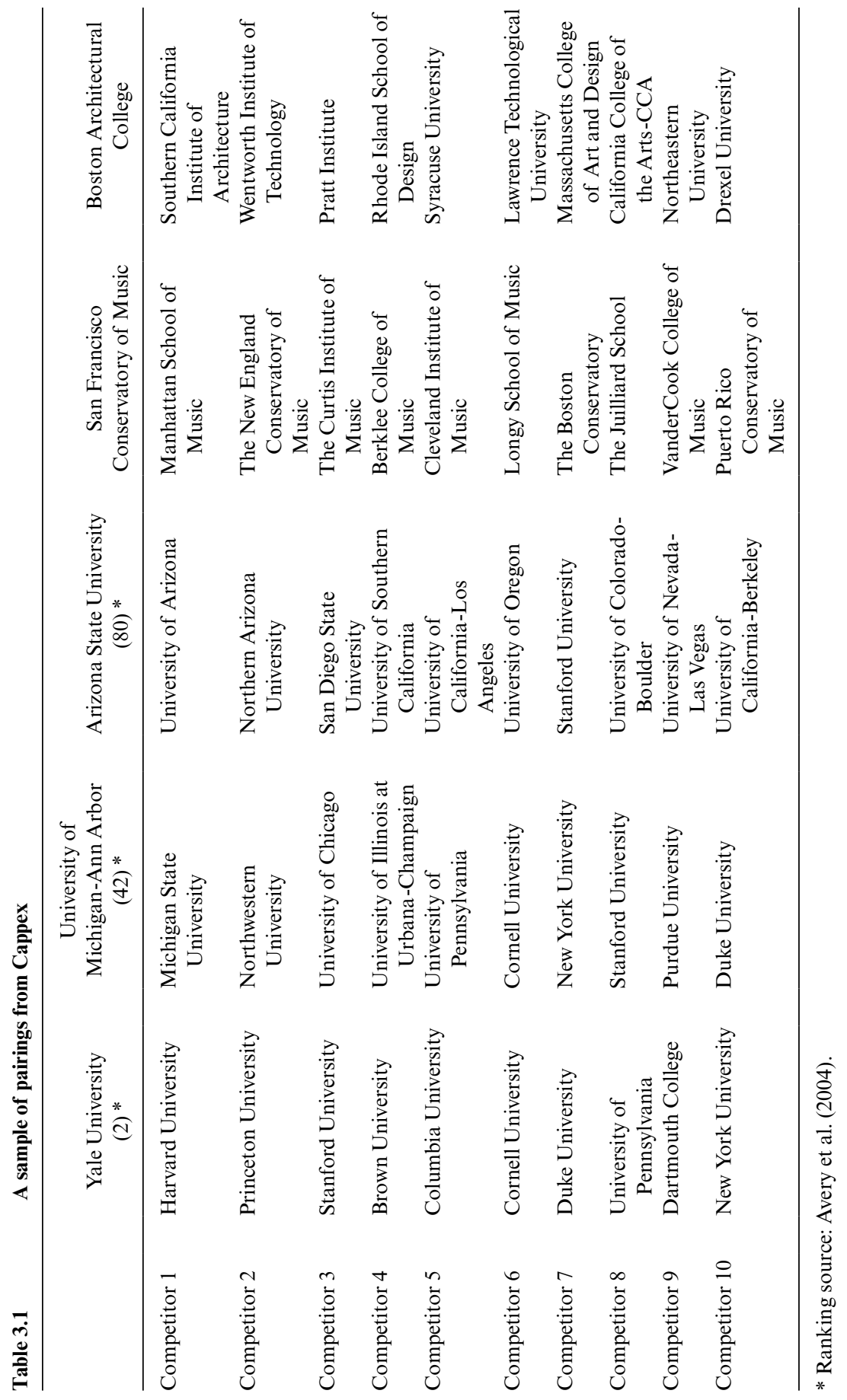




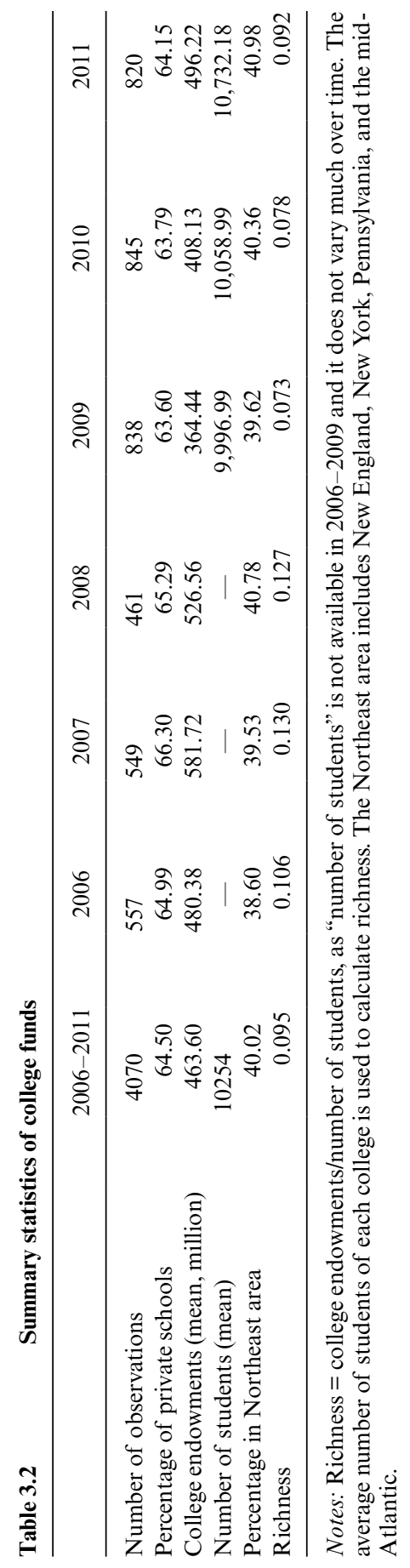


every one hundred million dollar increase in endowment size increases the percent of assets invested in marketable alternatives by 2.2 percent. A comparable increase in asset size increases the percent in all alternatives by 12 percent. Every thousand students, another measure of school size, increases the share in marketable alternatives by 1.3 percent and all alternatives by 1.9 percent. Smaller endowments, those below $\$ 25$ million, have a natural disadvantage in investing in marketable alternative funds since they may not meet the definition of a qualified institutional investor. In addition, hedge funds face a limit on the number of investors they can serve and this rationing process favors large investors. Larger schools have both the financial resources and the staff to consider alternative investments, although the scale of their investment offices may reflect the complexities of investing in alternative assets. Schools located in the New England or mid-Atlantic regions have, on average 3.5 percent more of their endowments invested in marketable alternatives, all else equal, and 3.8 percent in all alternatives. The regression also suggests that richer schools, measured by endowment per student, invest more in alternative assets, perhaps reflecting a higher taste for risk or a belief in their ability to carry illiquid assets.

The key variable in the regression from our point of view is the nearest competitor. Again, this variable measures the percent of alternative investments or marketable alternatives held by a school's ten nearest competitors. As we see, the variable is positive and highly significant both in explaining marketable alternatives and all alternative investments. In the pooled sample in column (1), a 1 percent increase in a rival's allocation to marketable alternatives increases own allocation to this asset class by .43 percent and all alternatives by .64 percent. Coefficients are roughly equivalent and all are significant across the six years in our sample.

We take these results to be consistent with our model of strategic asset allocation. Within school pairings, constructed to reflect competition among schools in the product market, we observe-holding constant size, richness, and location - very similar patterns of investments in alternatives.

In 2009, the NACUBO-Commonfund survey began asking endowment managers whether they were considering a change in their asset allocations and, if so, what change was being contemplated. Almost 25 percent of the sample reported in any given year were considering an allocation change. This in itself is interesting and is consistent with the transition of the endowment population observed over our longer period of study. In table 3.4, we estimate a log-linear regression, asking whether a manager's interest in changing plans is related to an endowment's own lagged performance and that of its nearest competitors. The results suggest that high-lagged own returns decrease the likelihood of wanted to change asset allocations, while good performance by an index of nearest competitors are associated with an increased likelihood of change. 


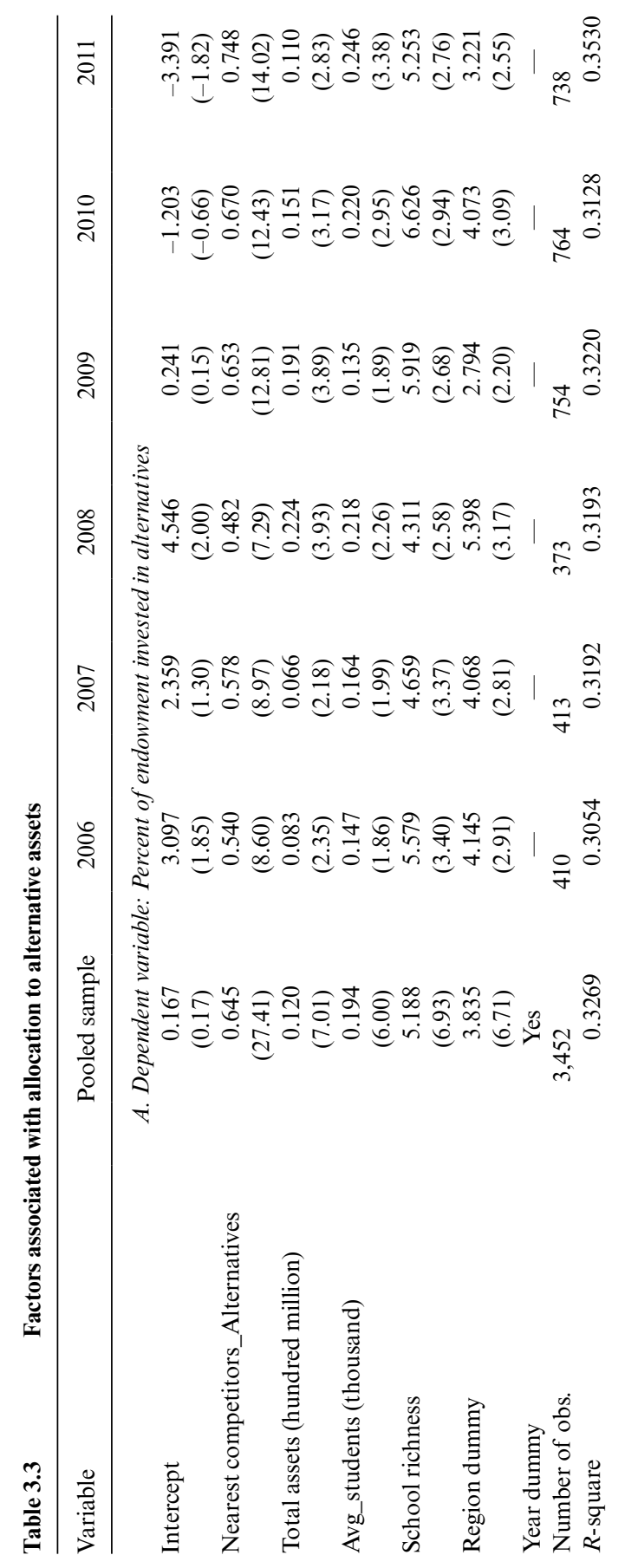




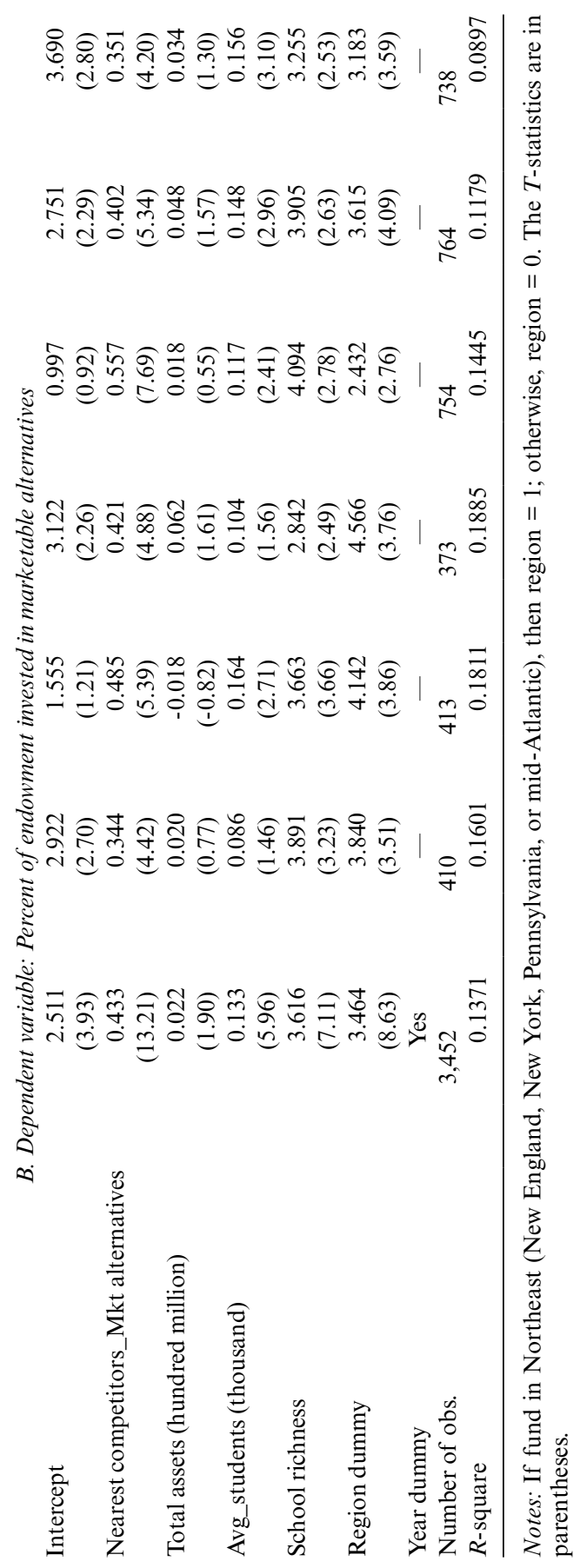




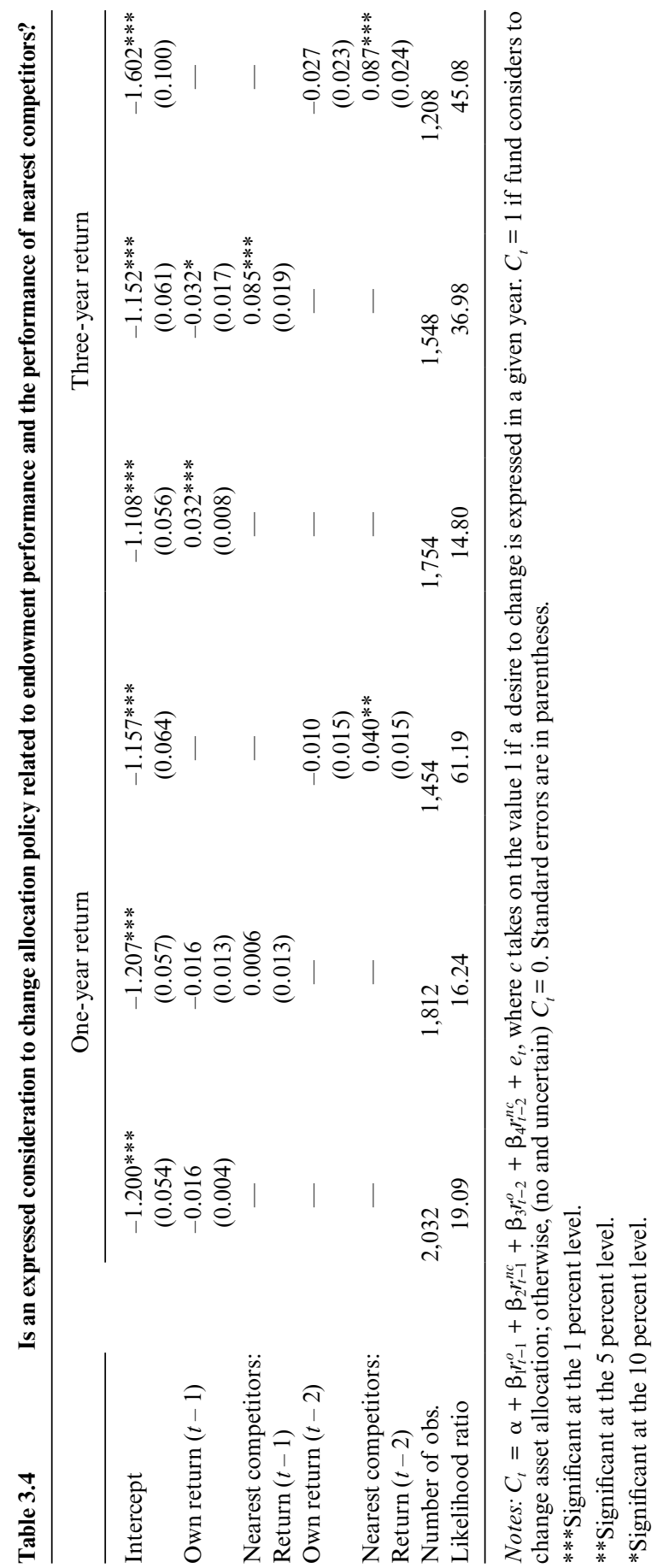


Table 3.5

Conditional policy change

\begin{tabular}{|c|c|c|c|c|c|}
\hline $\begin{array}{l}\text { Frequency } \\
\text { percent }\end{array}$ & Yes & No & Uncertain & Growth & Risk \\
\hline \multicolumn{6}{|c|}{ A. Three-year return } \\
\hline \multirow[t]{2}{*}{ Loser } & 210 & 475 & 75 & 0.673 & 0.817 \\
\hline & 27.63 & 62.50 & 9.87 & & \\
\hline \multirow[t]{2}{*}{ Winner } & 213 & 592 & 66 & 0.623 & 0.722 \\
\hline & 24.45 & 67.97 & 7.58 & & \\
\hline \multirow[t]{2}{*}{ Total } & 423 & 1067 & 141 & $\operatorname{Pr}=0.3701$ & $\operatorname{Pr}=0.0415$ \\
\hline & 25.94 & 65.42 & 8.65 & & \\
\hline \multicolumn{6}{|c|}{ B. Five-year return } \\
\hline \multirow[t]{2}{*}{ Loser } & 214 & 522 & 74 & 0.658 & 0.812 \\
\hline & 26.42 & 64.44 & 9.14 & & \\
\hline \multirow[t]{2}{*}{ Winner } & 169 & 439 & 57 & 0.632 & 0.713 \\
\hline & 25.19 & 65.97 & 8.85 & & \\
\hline \multirow[t]{2}{*}{ Total } & 383 & 961 & 131 & $\operatorname{Pr}=0.6583$ & $P r=0.045$ \\
\hline & 25.97 & 65.15 & 8.88 & & \\
\hline
\end{tabular}

Notes: For panel A, test of the independence of decision to consider an asset allocation change: yes/no: $P r>t=0.0734$; test of the difference in proportion for conditional response to considering a change toward growth-oriented assets: growth: $\operatorname{Pr}>t=0.3701$; test of the difference in proportion for conditional response to considering a change toward risk/hedgeoriented assets risk: $\operatorname{Pr}>t=0.0415$. For panel B, test of the independence of decision to consider an asset allocation change: yes/no: $\operatorname{Pr}>t=0.6052$; test of the difference in proportion for conditional response to considering a change toward growth-oriented assets: growth: $\operatorname{Pr}>t=0.6583$; test of the difference in proportion for conditional response to considering a change toward risk/hedge-oriented assets risk: $\operatorname{Pr}>t=0.0453$.

Table 3.5 further explores the type of change contemplated by endowments. Ideally, we are interested in whether superior performance by a rival drives an endowment more into alternatives. The survey data provides some interesting evidence in this regard. Table 3.5 examines comparative performance to the set of nearest competitors at three-year and five-year horizons. Winners are defined as those funds that beat their competitors over that time interval. Counts and proportions are reported, and test of the independence of rows and columns are also reported.

Consistent with the evidence in table 3.4, we find that, over the three-year horizon, the propensity to change is related to whether or not the fund is a winner or loser relative to competitors. This is positive, although the $p$-value is 7 percent, and over the five-year horizon, we do not reject the null. The focus of this table, however, is the further detail provided by endowments about the TYPE of change being contemplated. At both three- and five-year return horizons, losers contemplating a change were significantly more likely to seek assets in the risk/hedge category as opposed to the growth category. Unfortunately, the NACUBO classifications are not a perfect match for our interests. Choices for contemplated changes are: growth assets, defined as domestic and international equities, private equities, and so forth; risk 
reduction, defined as long/short, hedged equities, fixed income; inflation protection, defined as real assets (e.g., real estate, oil and gas, timberland, and TIPS); opportunistic investment (undefined); liquidity(undefined); and other. We use only the growth assets and risk reduction categories. Hedge funds are included in the risk reduction category along with fixed income. While it is generally true that hedge fund returns have lower standard deviations than equities, the common reasons to invest in them is to capture risk-adjusted returns (alpha) based on proprietary trading techniques. This makes hedge funds quite different from fixed income, with which they are lumped. With this caveat we can interpret the significant preference by losers for the risk reduction category provisionally as a tendency to move toward marketable alternatives as opposed to private equity, although it is also possible that it reflects a tendency to increase bonds. Note, however, that it is not the result of a movement toward more liquidity engendered by the 2008-2009 crisis - this would presumably fall into the liquidity category.

Table 3.6 follows up on the reported desire to change asset allocation. We take responses to the question about intent to change allocation and see whether the endowments in fact change their percentage allocation in the following year. The table treats the increase in percentage allocation each asset class in a separate regression, using the indicator variables for intent to change or uncertain about a change as explanatory variables. We also include a dummy for year 2011, to address secular changes in endowment preferences for certain asset classes. Since this question has only been asked for two years and we are using a one-year forward lag as the dependent variable, we only have two years of annual panel data.

The time dummy in the regression is significant in each case and indicates two things. First, it likely partly reflects change in the market value of each asset class - in years when the stock market goes up, it will be positive. Second, it also likely reflects industry-wide rebalancing toward certain asset classes. For example, although domestic equities increased in market value in fiscal year 2011, the coefficient on intent to change is negative, indicating that, controlling for market growth, endowments intending to change withdrew funds from domestic equities in the following year.

The coefficient on marketable alternatives is strongly positive, while the 2011 dummy is negative - the overall industry trend and/or the performance of hedge funds in 2011 may have been down, but for those endowments reporting an intent to change policy, they followed through by increasing their exposure to hedge funds. The same is true for international equities (which would include emerging market stocks), but interestingly it is not true for private equity and venture capital. This is consistent with the evidence we saw in the previous table - that, conditional on intent to change, the risk reduction category was significant for losers but not the growth assets category.

Finally, we use the data to explore whether the documented pattern of competitive response that has led endowments toward greater allocation to 


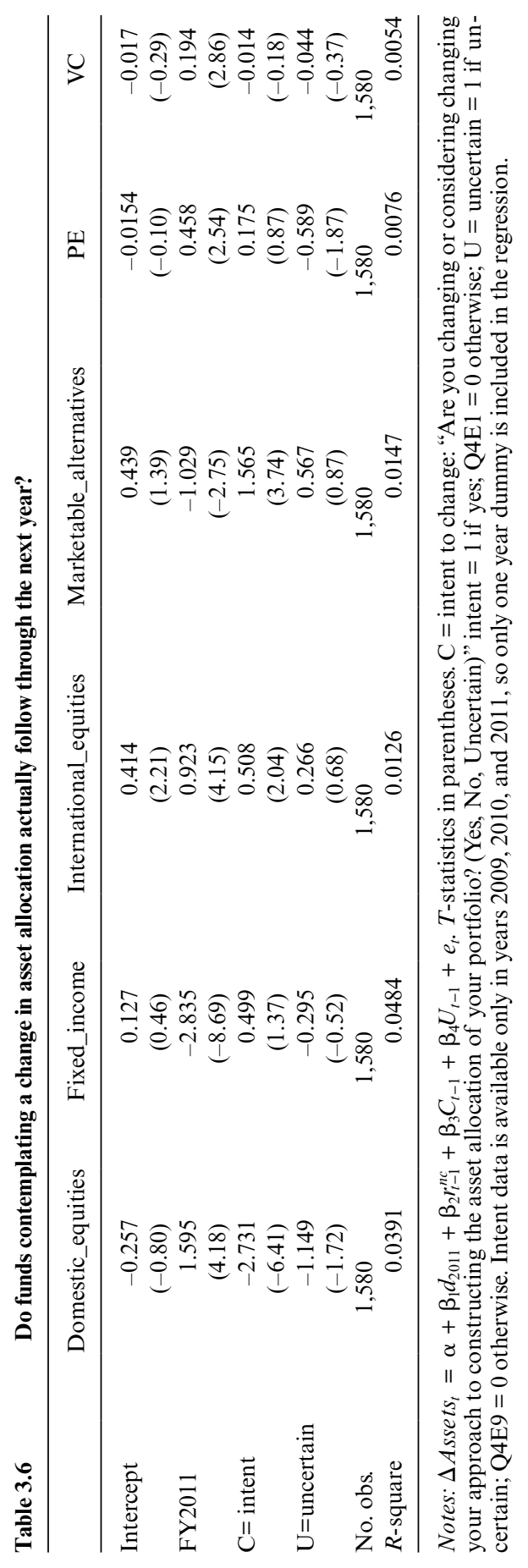


marketable alternatives has differential effects for large versus small institutions. Table 3.7 reports the results of regressions explaining the reported returns within each asset class. The explanatory variables include a benchmark index for that asset category in the observation year (for example, the domestic equities benchmark is the S\&P 500), the size and richness of the endowment at the beginning of the year, and a dummy for the Northeast region. Focusing in the marketable alternatives, we see that the benchmark explains performance well, but that certain factors add or detract. Taking the average values for endowment size (\$463 million) and richness (.095), the estimated model indicates that these add about .30 , or 30 basis points per year to the return to marketable alternatives. The Northeast dummy adds 57 basis points. Thus a school of average size and average richness situated in the Northeast would likely have a return that exceeds the benchmark $(0.868-$ $0.696=.182)$, which suggests that the hedge fund allocation has matched or exceeded industry performance. For less rich, smaller schools outside the Northeast this is likely not the case. Given the standard errors about the coefficient in the marketable alternative regression, however, this calculation is only a gross estimate: while the intercept is significantly negative, the other coefficients (besides the intercept) are not. Among the other regressions, the overall alternatives portfolio (constructed with reported asset weights) gives similar results, although the richness factor approaches standard significance levels. Performance from domestic equities, by contrast, does not vary at all by asset size, school richness, or region. Interestingly, though somewhat outside the scope of this chapter, we find that international equity performance also varies with endowment size, school richness, and region, suggesting that this asset class, like alternatives, requires more endowment management skill to pay off. This may give one some pause when we remember the small uptick in the general trend toward international equities in figure 3.5, and a significant loading on intent to change for the international equities regression in table 3.6.

\subsection{Discussion}

Our empirical results demonstrate a few things. First, we show that the college endowment allocations to alternative assets - and more specifically to marketable alternatives, is associated with the allocation policies of their near competitors and single-closest competitor. This is true even in controlling for regional effects, size, and richness. Second, we show that the decision by college endowments to change their asset allocations is not independent of the relative performance compared to rivals. In particular, prior one- and two-year past returns of rivals are positively associated with an intent to change allocation. We find that, conditional upon an intent to change, losing funds (i.e., those that underperformed rivals) more frequently indicated a choice for a category that includes hedge funds compared to winners who 


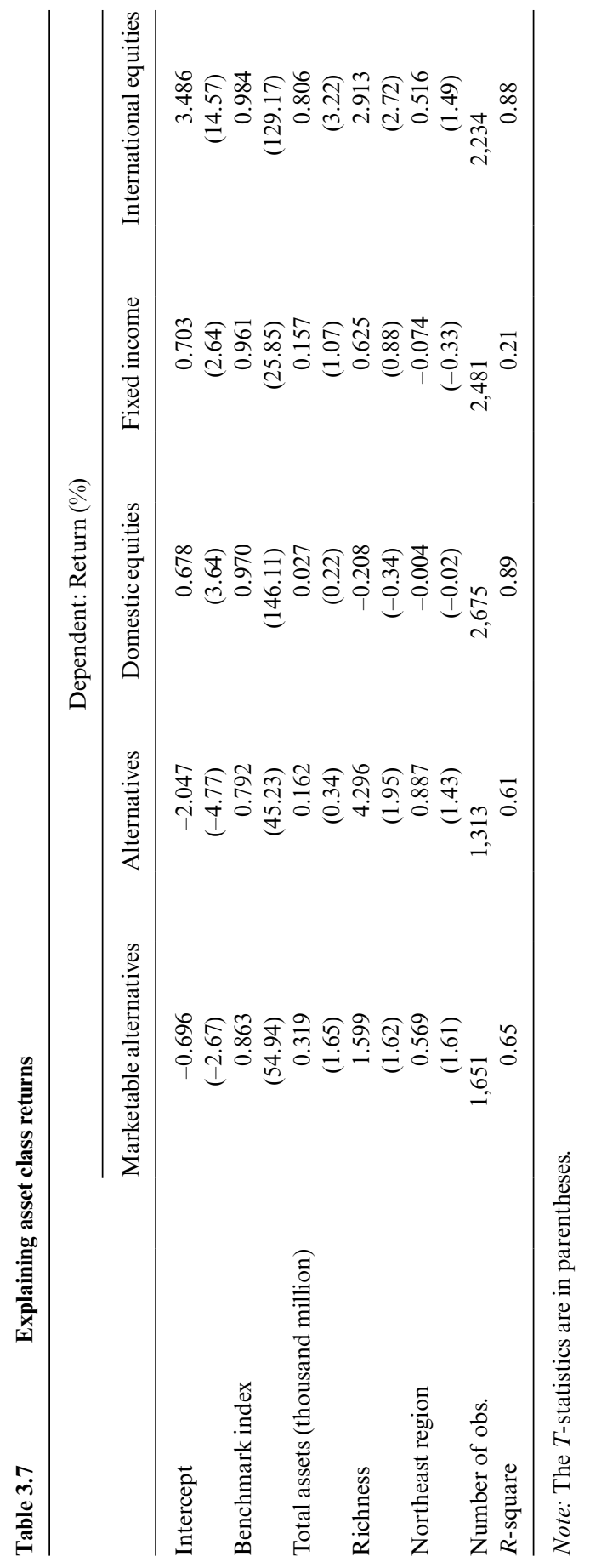


intended to change. This difference is not true for the asset category that includes private equity and venture capital. We find that the announced intent to change allocation is significantly related to a subsequent reduction in domestic equities and an increase in international equities and marketable alternatives.

These results are consistent with the hypothesis that the relative performance of a university's competitors' endowments influences its asset allocation policy and the decision to change it. The general direction of the change is also consistent with the trends set by HYP — toward marketable alternatives - that is, hedge funds.

The welfare effects of this allocation shift are unclear. The implication of DeMarzo, Kaniel, and Kremer $(2005,2008)$ is that keeping up with the Joneses can create positive externalities if, indeed, the action is welfare improving. After all, that is what new technology is all about. Is the shift to alternative investments a benefit to the universities who respond to competitive pressure by reallocating? The answer is not straightforward. There is considerable literature on the returns to hedge funds. Brown, Goetzmann, and Ibbotson (1999) find that hedge funds delivered positive risk-adjusted returns over the period 1989 to 1995. Ibbotson and Chen (2005) and Stulz (2007), in a review article, finds that this basic result holds true over a longer sample period. Perhaps the competition among university endowments has led to greater diversification, less exposure to market risk, and the utilization of manager skill. Unfortunately, time is needed to fully assess the benefits of a new technology. Our analysis of the relative benefits of small and less rich funds moving to marketable alternatives is constrained to recent years. With this qualification, we find some evidence that the benefits to the allocation shift are differential.

If the returns to marketable alternatives continue as they have historically, then the competition will have been a good thing. If, on the other hand, markets are efficient — or at least access to managers who can take advantage of inefficiencies for the benefit of clients is limited - then this shift may have long-term costs. One lesson of the Great Recession is that allocation into less liquid alternatives such as private equity increases endowment exposure to emergency demands on cash. While this may be a source of higher expected returns for investors with a long horizon, the shock of 2008 has likely caused a recalibration of institutional sensitivity to financial crises.

\section{References}

Abel, Andrew B. 1990. "Asset Prices under Habit Formation and Catching up with the Joneses." The American Economic Review 80 (2): 38-42. Papers and Proceed- 
ings of the Hundred and Second Annual Meeting of the American Economic Association.

Avery, Christopher, Mark Glickman, Caroline Hoxby, and Andrew Metrick. 2004. "A Revealed Preference Ranking of US Colleges and Universities." NBER Working Paper no. 10803, Cambridge, MA.

Bakshi, Gurdip S., and Zhiwu Chen. 1996. "The Spirit of Capitalism and StockMarket Prices.” American Economic Review 86 (1): 133-57.

Bastedo, Michael N., and Nicholas A. Bowman. 2011. "College Rankings as an Interorganizational Dependency: Establishing the Foundation for Strategic and Institutional Accounts." Research in Higher Education 52 (1): 3-23.

Brown, Keith, Lorenzo Garlappi, and Cristian Tiu. 2010. "Asset Allocation and Portfolio Performance: Evidence from University Endowment Funds." Journal of Financial Markets 1:268-94.

Brown, Keith, W. V. Harlow, and L. T. Starks. 1996. "Of Tournaments and Temptations: An Analysis of Managerial Incentives in the Mutual Fund Industry." Journal of Finance 51:85-110.

Brown, Stephen J., William N. Goetzmann, and Roger G. Ibbotson. 1999. "Offshore Hedge Funds: Survival and Performance, 1989-95.” Journal of Business 72 (1): 91-117.

Brown, Stephen J., William N. Goetzmann, and James Park. 2001. "Careers and Survival: Competition and Risk in the Hedge Fund and CTA Industry." Journal of Finance 56 (5): 1869-86.

Burke, Mary, and Tim Sass. 2008. "Classroom Peer Effects and Student Achievement." Working Paper no. 08-5, Federal Reserve Bank of Boston.

Chan, Yeung Lewis, and Leonid Kogan. 2002. "Catching Up with the Joneses: Heterogeneous Preferences and the Dynamics of Asset Prices." Journal of Political Economy 110 (6): 1255-85.

Chevalier, Judith A., and Glenn D. Ellison. 1997. "Risk Taking by Mutual Funds as a Response to Incentives.” Journal of Political Economy 105 (6): 1167-200.

DeMarzo, Peter M., Ron Kaniel, and Ilan Kremer. 2005. "Diversification as a Public Good: Community Effects in Portfolio Choice." Journal of Finance 59 (4): 1677-716.

- 2008. "Relative Wealth Concerns and Financial Bubbles." Review of Financial Studies 21 (1): 19-50.

Epple, Dennis, Elizabeth Newlon, and Richard Romano. 2002. "Ability Tracking, School Competition and Distribution of Educational Benefits." Journal of Public Economics 83:1-48.

Epple, Dennis, Richard Romano, and Holger Sieg. 2003. "Peer Effects, Financial Aid and Selection of Students into Colleges and Universities: An Empirical Analysis." Journal of Applied Econometrics Special Issue: Empirical Analysis of Social Interactions 18 (5): 501-25.

2006. "Admission, Tuition, and Financial Aid Policies in the Market for Higher Education." Econometrica 74 (4): 885-928.

Galí, Jordi. 1994. "Keeping up with the Joneses: Consumption Externalities, Portfolio Choice, and Asset Prices." Journal of Money, Credit and Banking 26 (1): 1-8.

Goetzmann, William N., John Griswold, and Yung-Fang (Ayung) Tseng. 2010. "Educational Endowments in Crises." Journal of Portfolio Management 36 (4): $112-23$.

Griliches, Zvi. 1957. "Hybrid Corn: An Exploration of the Economics of Technological Change." Econometrica 25 (4): 501-22.

Hoxby, Caroline. 2009. "The Changing Selectivity of American Colleges." Journal of Economic Perspectives 23:95-118. 
Ibbotson, Roger G., and Peng Chen. 2005. "Sources of Hedge Fund Returns: Alphas, Betas, and Costs." Working Paper no. 05-17, Yale International Center for Finance, Yale University.

Lerner, Josh, Antoinette Schoar, and Jialan Wang. 2007. "Secrets of the Academy: The Drivers of University Endowment Performance." Harvard Business School of Finance, Working Paper no. 07-066, Harvard University.

Litvak, J., Burton Malkiel, and Richard Quandt. 1974. "A Plan for the Definition of Endowment Income." American Economics Review 64:433-37.

Oster, Sharon. 1982. "The Diffusion of Innovation among Steel Firms." Bell Journal of Economics 13 (1): 45-56.

Ravina, Enrichetta. 2005. "Habit Persistence and Keeping Up with the Joneses: Evidence from Micro Data." NYU Working Paper no. FIN 05-046, New York University, November.

Shumway, David R. 1997. "The Star System in Literary Studies." PMLA Special Topic: The Teaching of Literature 112 (1): 85-100.

Sirri, Erik R., and Peter Tufano. 1998. "Costly Search and Mutual Fund Flows." Journal of Finance 53 (5): 1589-1622.

Stulz, René. 2007. "Hedge Funds: Past, Present, and Future.” Journal of Economic Perspectives 21 (2): 175-94.

Swensen, David. 2000. Pioneering Portfolio Management. New York: Free Press.

Tobin, James. 1974. "What is Permanent Endowment Income?" American Economic Review 64:427-32.

Volkwein, J. Fredericks, and Kyle V. Sweitzer. 2006. "Institutional Prestige and Reputation among Research Universities and Liberal Arts Colleges." Research in Higher Education 47 (2): 129-48. 